\title{
Osteoblasts and their applications in bone tissue engineering
}

\author{
This article was published in the following Dove Press journal: \\ Cell Health and Cytoskeleton \\ 7 May 2012 \\ Number of times this article has been viewed
}

\author{
Asha Rupani' \\ Richard Balint ${ }^{2}$ \\ Sarah H Cartmell ${ }^{1,2}$ \\ 'Institute of Science and Technology \\ in Medicine, Keele University, \\ Hartshill, Stoke-on-Trent, UK; \\ ${ }^{2}$ Materials Science Centre, \\ The University of Manchester, \\ Manchester, UK
}

\begin{abstract}
Tissue engineering is an emerging therapy that offers a new solution to patients suffering from bone loss. It utilizes cells derived from such sources as a patient's own bone or bone marrow, which are laboratory-isolated, grown (so they multiply in number), and placed onto a degradable material, or scaffold, that has mechanical/chemical properties appropriate to the bone section that it is replacing. The cells plus the scaffold are then grown in a container, or bioreactor, which is necessary as it provides the correct environment required for the cells to proliferate, differentiate, and to produce extracellular matrix. The following review focuses on the use of osteoblasts for bone tissue engineering.
\end{abstract}

Keywords: osteoblast, bone, tissue engineering, regenerative medicine, orthopaedic

\section{Osteoblasts, osteocytes, and osteoclasts}

The musculoskeletal system of the human body acts as a scaffold while enabling its various activities and protecting the vital internal organs. ${ }^{1-3}$ Bone also helps in maintaining the mineral homeostasis and provides a niche for hematopoietic stem cells. ${ }^{1,3,4}$ Bone is constantly undergoing remodeling and is a highly dynamic tissue with good regeneration capacity. ${ }^{1,2}$ It is made up of $25 \%$ water content, with collagen, along with other organic proteins, forming around $30 \%$ of the solid portion, and the rest, $70 \%$, is made up of the inorganic mineral hydroxyapatite. The collagen provides the bone with tensile strength and flexibility, whereas mineralization increases the stiffness and the compressive strength of the bone at the expense of its energy-storing capacity.

\section{Types of bone cells}

There are three major types of mature bone cells within the body: osteocytes, osteoclasts, and osteoblasts. Their roles are demonstrated schematically in Figure 1 in addition to osteoprogenitors. ${ }^{1-3,5}$

Osteocytes, the most abundant cells in the bone, are derivatives of the terminally differentiated osteoblasts and are present in the lacunae within the mineralized matrix. They have around 80 cytoplasmic processes that are $15 \mu \mathrm{m}$ in length and form a three-dimensional network - a connected cellular network - which makes them sensory cells in the bone for mechanotransduction. ${ }^{6,7}$ Osteoclasts (of macrophage lineage) are responsible for bone resorption and can be recognized by their multinuclearity and positive tartrate resistant acid phosphatase staining. ${ }^{1,5}$
Correspondence: Sarah Cartmell School of Materials, Materials Science Centre, The University of Manchester, Manchester MI 7HS, UK

Tel +44 I6I 3063567

Fax +44 I6I 3063586

Email sarah.cartmell@manchester.ac.uk 


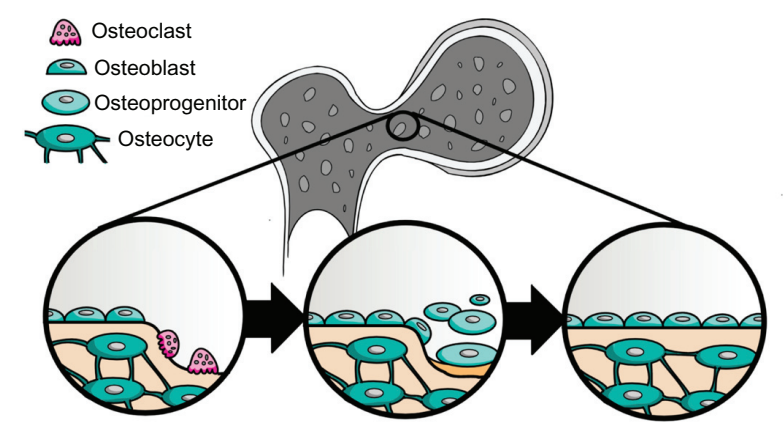

Figure I Bone remodeling is a continuous process in vivo, is vital for the healing of normal and microfactures, and is responsible for the adaptability of our bones to various loading conditions.

Notes: Left: osteoclasts break down bone tissue through resorption. Center: this in turn causes the bone progenitor cells to be recruited to the area and to be differentiated into osteoblasts, while the osteoblasts already present, lining the surface of the bone tissue, proliferate. Right: the osteoblasts reform bone through a process called ossification, while some of them differentiate into mature bone cells - osteocytes.

Osteoblasts ("osteo" = bone, "blast" = germ or embryonic) are secretory cells, forming unmineralized collagen-rich osteoid (in which subsequently the mineralization occurs) comprising bony matrix proteins such as type I collagen and other non-collagenous proteins such as osteopontin, osteocalcin, osteonectin, osteoprotegerin (OPG), bone morphogenetic proteins (BMPs), and glycoproteins. ${ }^{2,3,5,6}$ They are mononuclear cells, around $15-30 \mu \mathrm{m}$ in size, with a spherical nucleus and abundant basophilic cytoplasm comprising rough endoplasmic reticulum, golgi apparatus, and mitochondria, along with active cytoskeletal proteins. ${ }^{3,5}$ During osteoblastic differentiation, progressive stages of cell maturation and differentiation have been characterized from osteoprogenitors to the osteocytes and lining cells. ${ }^{8}$

Osteocytes, osteoblasts, and to some degree osteoclasts form an interconnected network allowing for communication and transport between the osteocytes deep within the tissue and the osteoblasts and osteoclasts located within the vicinity of vascular spaces and bone surfaces to which the loads are conveyed. ${ }^{6,7}$ The neighboring osteoblasts and osteocytes are connected with numerous gap junctions that allow coordinated cellular activity, whereas the intercellular communication in the form of a calcium signal exists between osteoblasts and osteoclasts and among osteoclasts via $\mathrm{P} 2 \mathrm{Y}$ and $\mathrm{P} 2 \mathrm{X}_{7}$ receptors, respectively. ${ }^{7,910}$ Committed stromal cells of osteoblastic lineage through cell-to-cell contact encourage the differentiation of osteoclastic progenitors and their fusion to form multinucleated active osteoclasts. ${ }^{11,12}$ Similarly, the osteoclasts exert control over the osteoblasts, depending on their stage of differentiation, and the coupling is influenced by the catabolic effect induced by parathyroid hormone (PTH), receptor activator for nuclear factor $\mathrm{\kappa B}$ ligand (RANKL), as well as its reversal by soluble antagonist osteoprotegerin. ${ }^{1,3,8}$ This communication network is illustrated in Figure 2.

\section{Role of osteoblasts in development, function, and repair of bone and consequences of osteoblast dysfunction Embryology}

Embryologically, bone is derived from the mesenchymal condensations via intramembranous or endochondral ossification. ${ }^{1,3,5,13}$ In the former case, the bone is formed via the mesenchymal stem cells (MSCs) (or otherwise termed osteoprogenitors) differentiating directly into osteoblasts by expression of transcription factors such as core binding factor alpha-1 (Cbfa-1)/runt-related gene 2 (RUNX2), SP7/osterix (a zinc containing nuclear factor), Msx2, and various bone-related proteins within the membranes of condensed, vascularized primitive mesenchyme at the ossification centers. ${ }^{3,6,13-16}$ The osteoblasts proliferate around the newly formed blood vessels, laying down the bony matrix and enclosing themselves. In the case of the latter, initial intermediate cartilage is observed at the epiphyseal ends of the embryonic long bones. ${ }^{1,13}$ Chondrocytes expressing type II collagen lay down the cartilaginous matrix, which is consequently penetrated by a blood capillary network. This blood vessel-invaded cartilage subsequently matures as

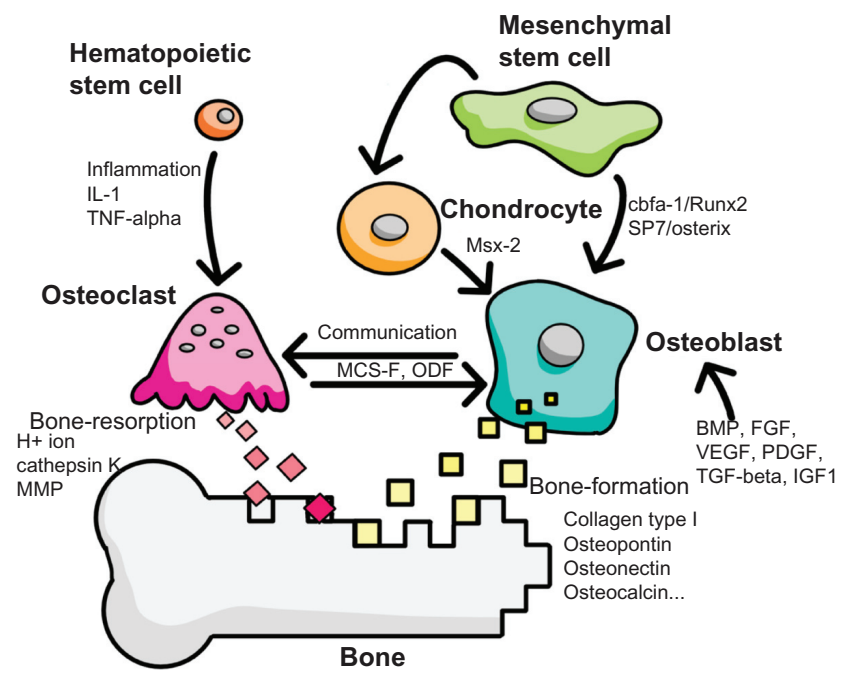

Figure $\mathbf{2}$ The two bone cell types responsible for bone remodeling and their origins. Note: Osteoclasts, descending from hematopoietic stem cells, break down bone, while osteoblasts, descending from mesenchymal stem cells, lay down new extracellular matrix and thus reconstruct bone.

Abbreviations: IL, interleukin; TNF, tumor necrosis factor; MMP, matrix metalloprotease; BMP, bone morphogenetic protein; FGF, fibroblastic growth factor; VEGF, vascular endothelial growth factor; PDGF, platelet-derived growth factor; TGF, transforming growth factor; IGF, insulin growth factor. 
type X collagen is produced by hypertrophic chondrocytes. This initiates calcification of the local extracellular matrix. The growth of cartilage pushes the epiphysis from the shaft, and on the other side the osteoblasts invade, progressively replacing the cartilage. Simultaneously, remodeling by the osteoclasts forms the marrow cavity and shapes the bone.

\section{Role of osteoblasts in bone repair and influencing factors}

Osteoblasts are an important player in the formation, growth, and repair of the bone, as they are solely responsible for formation of the bony matrix. Bone development and repair are finely coordinated by the balance between resorption and creation of the bone matrix by osteoclasts and osteoblasts, respectively. ${ }^{1,2,17}$ Together, they form basic multicellular units, present in the vicinity of the vascular spaces and bone surfaces, responsible for bone modeling and remodeling via the "RANKL-RANKosteoprotegerin" axis. ${ }^{7,8,18-20}$ Following any trauma to the bone, disruption of the vasculature leads to haematoma formation and recruitment of the osteoprogenitor cells from the endosteum and periosteum to the fracture site. ${ }^{2,14}$ Subsequently, there is direct intramembranous bone formation in the periosteum, leading to the formation of the callus with simultaneous angiogenesis. The process is then completed by osteoclasts, which remodel the fracture site to achieve an appropriate geometry. ${ }^{1,2}$ Shirley et al have reported that some of the osteoblasts involved in fracture healing are systemically mobilized and recruited to the fracture site from the remote bone marrow via circulation. ${ }^{21}$

At the diaphysis, the diameter of the bones increases by appositional ossification. This is where the aligned osteoblasts deposit extracellular matrix beneath the periosteum, forming ridges and pockets that entrap the blood vessels. These ridges then fuse, encircling the blood vessels and the osteoblasts that laid down the matrix, forming the typical osteon. ${ }^{1,3,5}$ Osteoblastic activity is influenced by various factors like BMPs, fibroblastic growth factors, transforming growth factor- $\beta$, platelet-derived growth factor, vascular endothelial growth factor (VEGF), insulin growth factor-1, LIM-mineralization protein-1, prostaglandins, interleukins, and reactive oxygen species. ${ }^{1-3,6,14,22,23}$ Bone formation and nourishment also require optimal concentrations of oxygen. As bony tissue is highly dense, the nutrients cannot be diffuse over long distances and they therefore require a highly efficient vascular supply. ${ }^{2}$ It is important to understand these physiological mechanisms of bone development and repair, as they guide us in the choice of ideal conditions and biochemicals to engineer viable bone grafts.

\section{Role of angiogenesis in osteogenesis}

Angiogenesis is also an important part of osteogenesis during development and fracture repair and is executed by the osteoprogenitor cells from the marrow present in the medullary canal of the bones. ${ }^{1,14,24}$ Any alterations in the vascular supply to the bone tissue could lead to various skeletal pathologies, such as osteonecrosis, osteomyelitis, or osteoporosis. ${ }^{14}$ VEGF has been demonstrated to be constitutively expressed in three-dimensional environments in vitro studies by the preosteoblastic cells (as detected by gene expression analysis) within 1 week. ${ }^{25}$ VEGF-A plays an important role in the process of endochondral ossification due to its chemoattractive and proliferative properties on primary osteoblasts as well as MSCs in a dose-dependent manner (at a reported concentration of $10 \mathrm{ng} / \mathrm{mL}$ ). ${ }^{26,27} \mathrm{In}$ an in vivo study conducted by Kleinheinz et al in rabbits, filling the mandibular defects with rhVEGF incorporated collagen showed increased density of bone with persisting higher numbers of blood vessels as compared to control cases by day $14 .{ }^{28}$ VEGF acts indirectly by stimulating the synthesis of CCN1, which is an extracellular matrix signaling molecule that has been implicated in neovascularization through its interactions with several endothelial integrin receptors and osteoblasts during a fracture healing in mice model. ${ }^{24}$

With these very different methods that the body uses to develop and repair bony tissue, we can draw useful information. We will refer back to these biological processes later in the review. It is also worth noting that mechanical stimuli in vivo helps in the proliferation of the cells and can lead to increased production of the extracellular matrix and expression of relevant genes in the bone cells. ${ }^{29-31}$

\section{Impact of bone dysfunction}

Defects in differentiation and function of osteoblasts have a large impact on the skeletal system, as evidenced by numerous genetic and acquired diseases of the skeleton. ${ }^{1,6}$ The bone loss or dysfunction due to degeneration, pathology, or trauma leading to interference of the normal skeletal environment is one of the major health concerns with huge socioeconomic implications. The growing elderly population (the projected annual increase being $2 \%-3 \%$ in the global 65 -plus population) is also leading to an increase in bone-related degenerative diseases such as osteoporosis, which is due to the hormonal changes and oxidative stress related to aging. $2,8,32,33$ The reduction in the bone mass during aging is mainly due to a decrease in the number of the osteoblasts rather than their functioning capacity, which could be due to reduced 
osteoblastogenesis or increased apoptosis. ${ }^{1,34}$ Each year, there are some 150,000 fractures due to osteoporosis..$^{35,36}$ According to the National Osteoporosis Society, each year the National Health Service has to spend a massive amount of money as a result of osteoporosis-related fractures, and the total cost of treating hip fractures alone amounts to more than $£ 1.73$ billion in the United Kingdom. ${ }^{36}$ It is also important to consider the individual patient's viewpoint, as bone diseases have a troubling impact on patients' overall physical and mental health that may ultimately conclude in premature death. Day-to-day functioning is severely restricted due to significant pain and limitation of movement leading to complications like pressure sores or increased infections. Often there is also a detrimental impact on the confidence of an elderly individual, leading to psychological consequences due to potential deformity and fear of falling. ${ }^{36}$

\section{Current therapeutic strategies}

There are several methods currently to treat bone defects, and typical therapies are described in the schematic in Figure 3. The pros and cons for each technique are also listed.

Though bone has a good regenerative capacity, sometimes repair in large defects requires aid for optimal healing. ${ }^{6,37}$ Routinely, the first option in bone diseases is reconstructive

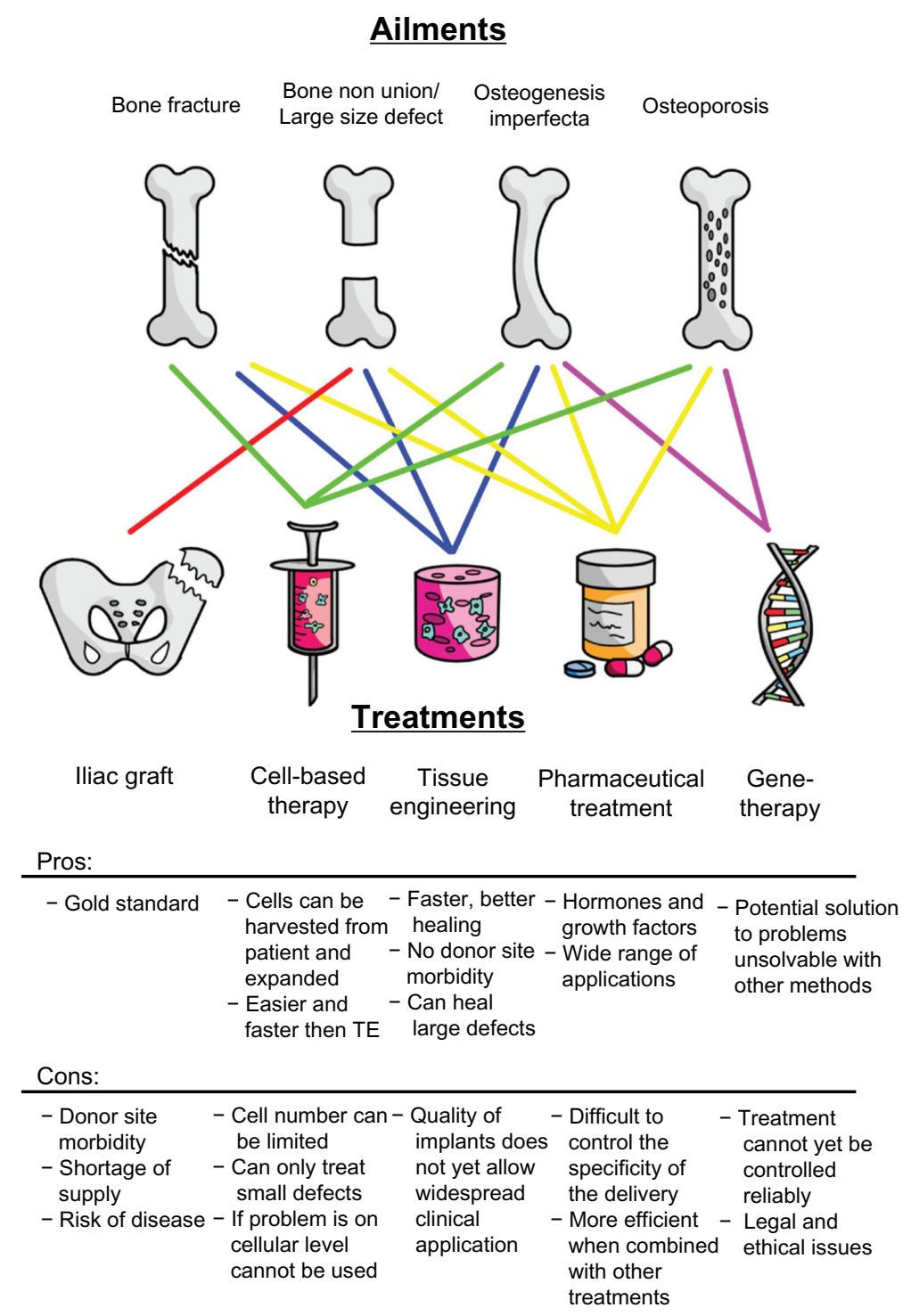

Figure 3 Novel treatments for common bone trauma and diseases.

Notes: No single treatment method alone can effectively cure all of these bone diseases. Each approach has its own benefits and limitations, and most of the time their combined application is necessary to deliver a truly effective treatment.

Abbreviation: TE, tissue engineering. 
surgeries - techniques that require precise execution. ${ }^{38,39}$ If this is not possible, then bone substitutes are required (in cases such as nonunion of fractures, bone neoplasias including metastatic deposits, osteomyelitis, osteonecrosis, bone cysts, spinal fusions, and reconstructive surgery in case of genetic disorders like osteogenensis imperfecta); otherwise, the patients' quality of life suffers extensively. ${ }^{3,6}$ Certain studies with the help of mathematical models have simulated the metabolic bone diseases, such as vitamin D deficiency, senescence, and glucocorticoid excess, and suggested that bone formation therapies yield better results than antiresorptive therapies, indicating that increasing the size of the pool of preosteoblasts is essential for the therapeutic manipulation of bone formation. ${ }^{8}$ Autologous iliac bone chip graft is considered the gold standard in bone repair, though in a 3-year retrospective study conducted by Albert et al, allografts (freeze-dried bone used in $80 \%$ of cases) were 10 times more commonly used than autografts. ${ }^{40}$ Allografts were used in $10.7 \%-12.7 \%$ as against $0.9 \%-1.3 \%$ of autografts in all orthopedic procedures. ${ }^{40}$ However, these traditional treatment protocols for bone repair are associated with inherent problems connected with harvesting, donor site morbidity, shortage of supply, risk of disease transmission, and unwanted immunological response. ${ }^{4,6,14,40-44}$ Synthetic grafts or implants made up of various biomaterials like metals, ceramics, and certain polymers have also received well-deserved attention, but they have their own limitations in the form of implant failures leading to revision surgery. ${ }^{6,43-45}$ Newer surgical techniques, cell-based (osteogenic cells such as osteoblasts and MSCs), scaffold-based (such as hydroxyapatite coated collagen type I - HEALOS), and pharmacologic-based therapies (such as recombinant human BMP-2) are in the experimental stages. ${ }^{6,46-52}$ Injections of autologous MSCs along with substrates like collagen, demineralized bone matrix, or ceramics are also being tried. ${ }^{5,53,54}$ In order to improve the functionality of the repair tissue created via the techniques listed above, bone tissue engineering techniques are being developed as discussed below.

\section{Applications in bone tissue bioengineering}

Bone tissue engineering is an interdisciplinary field with the purpose of repairing and replacing diseased bone with viable bone tissue that has been fabricated in the laboratory. ${ }^{6,35,37,55}$ The earliest attempts at engineering bone were made by Vacanti et al in the early 1990s. s6,57 $^{56}$ There are three important pillars of tissue engineering: cells, scaffolds, and the environment (the bioreactor) in which the cells are grown on the scaffolds. ${ }^{6,46,58}$ These different factors are demonstrated schematically in Figure 4. ${ }^{59-61}$

\section{Different cell sources, including role of primary osteoblasts in bone tissue engineering}

Cell sourcing is a major issue in bone tissue engineering, and ideally they need to be readily available in sufficient quantities, have consistent osteogenic potential, and be nonimmunogenic and nontumorigenic. ${ }^{6,62}$ Only when osteoblastlike cells are grown successfully in the laboratory while expressing the bone markers and secreting the appropriate extracellular matrix proteins can bone formation in vitro be achieved. ${ }^{18}$ Cell-based therapies expedite bone regeneration in vivo without depending on local factors. ${ }^{46,52,63}$ The current literature details a variety of different cells for bone tissue

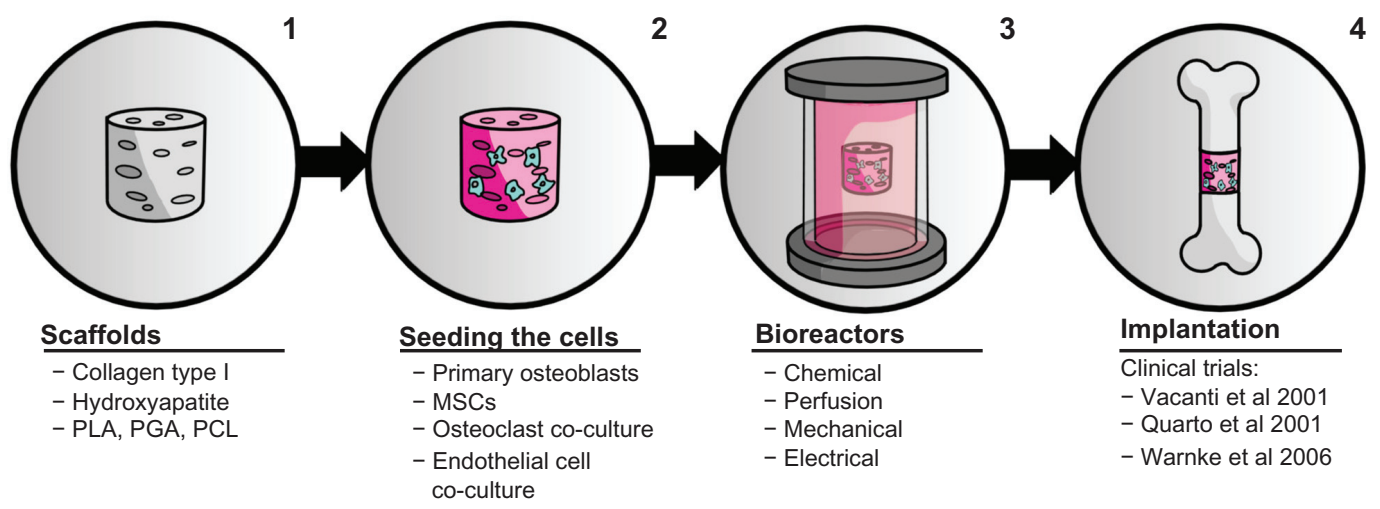

Figure 4 The in vitro tissue engineering approach in four steps. (I) A biomaterial scaffold, may be a flat sheet to mimic skin, a bundle of fibers to replace tendons or a three-dimensional cylinder to be implanted into bone. (2) The construct is bioactivated with primary or stem cells. (3) After seeding the cells, the construct is cultured in a bioreactor, simulating at least one aspect of the in vivo environment (eg, chemistry, mechanical stresses). (4) The final step is the implantation and, if possible, ex vivo monitoring of the behavior of the construct. 
engineering experiments. These cells - osteoprogenitor cells, various commercially available cell lines, and primary osteoblastic cells - are chosen depending on the stage of technique optimization that the researcher is intending to investigate. For example, an in vitro study that is closer to the clinic may utilize primary human MSCs or osteoblasts (as these cells could potentially be the final type of cell source used in the tissue engineered product being developed). Another study may utilize a murine MC3T3-E1 continuous cell line in its set of in vitro studies, which obviously could not be used in a final tissue engineered bone implant, but will give information as to the response of a well-characterized and standardized osteoblast-like cell in a particular set of stimuli.

Stem cells, being self-renewing, provide a continued source of cells, and the osteogenic potential of the multipotent MSCs from various sources like bone marrow, cord blood, adipose tissue, dental pulp, synovium, or periosteum has been recognized for over a decade..$^{6,45,55,58,64-77}$ These can be either autologous or allogeneic, as they have low immunoreactivity and their osteogenic potential can be accelerated by various chemicals, growth factors, mechanical stimulation, and gene therapy. ${ }^{3,6,60,78,79}$ The concept of injecting bone marrow at the site of bone defect for speedy recovery is based on the fact that it makes osteoprogenitor cells easily available if optimal cell concentration is provided. ${ }^{3,42,80,81}$ In addition, the yield can be increased by selectively using STRO-1-positive MSCs or CD34-negative cells. ${ }^{77}$ It has been reported that the source of MSCs is equally important and osteoprogenitor cells derived from the periosteum are most proliferative, followed by cortical bone, cancellous bone, and bone marrow aspirate. ${ }^{65}$ However, the effect of senescence of MSCs, which can lead to reduced osteogenic potential, has to be kept in mind. ${ }^{82}$ There are a few reports describing directed differentiation of embryonic stem cells into osteogenic cells where the progress was hindered (due to ethical constraints and issues of immunogenicity and tumorigenicity), even though they have advantages of unlimited in vitro growth potential, accessibility, and ease of genetic manipulation. ${ }^{6,64,83}$

Use of primary predifferentiated osteoblastic cells would be most advisable, as they can be autologous, especially for clinical applications, and start producing bone matrix immediately, but due to their restricted proliferation in vitro their role has been limited until now. , $6,58,84-86^{\text {They can be }}$ derived from bone chips by enzymatic extraction of cells and expanded by further in vitro culture. There are very few studies that report the use of primary osteoblasts directly, rather than MSCs differentiating into osteoblasts. ${ }^{18,85,86}$ Wiesmann et al cultured periosteal derived osteoblasts in petri dishes and in collagen gel in monolayers and demonstrated production of extracellular matrix production along with mineralization. ${ }^{18}$ Gentleman et al compared the quality of bone produced by different types of cells, and they reported that osteoblasts and MSCs produced biomimetic tissue, as compared to embryonic stem cells, which was deficient in mineralization. ${ }^{87}$

All the studies mentioned above have either been performed in vitro or in vivo in small and large animal models like mouse, rat, sheep, goat, or dog. ${ }^{88}$ In vitro studies generally help to study the process of osteogenesis by different cells and to test the cytocompatibility of the biomaterials used to make the scaffolds (in terms of geometry and chemical composition), and further in vivo studies will help us to understand whether the observations made in vitro can be translated in vivo. ${ }^{6,60,88,89}$

Various cell lines are available for research purposes to study cell-biomaterial interactions, as they are easy to grow and their results can be compared, but they have their own limitations. ${ }^{84}$ Examples are MG-63 osteoblast-like cells that are human osteosarcoma cells and hence may not fully represent the behavior of native human osteoblasts. Stably transfected human fetal osteoblastic cell lines like hFOB 1.19, which closely resemble human osteoblasts, are available. MC3T3-E1, a cloned murine cell line (originating from mouse calvarial fibroblasts), and other xeno cells are widely used, but interspecies differences have to be kept in mind. It has been reported that rodent MSCs cultured with BMPs differentiate into osteoblasts, whereas most human MSCs show a poor osteogenic response to BMPs and require modulation of ERK and PI3K pathways. ${ }^{90,91}$

\section{Scaffolds used in bone tissue engineering}

Ideally, the scaffold used must be osteoconductive (allow bone cells to proliferate), osteoinductive (induce proliferation and differentiation of undifferentiated cells into osteoblasts), and the environment osteogenic to provide a reservoir of stem and osteoprogenitor cells that can form new bone. ${ }^{44,62}$ Appropriate geometry of the scaffold is also equally important, with porosity to enable mass transfer, providing increased surface areas for the cells to grow and act as carrier for growth factors. ${ }^{6,92}$ Pore size plays an important role, as larger pore size weakens the scaffold, whereas smaller pore size hampers neovascularization. Generally, pore size of $300-500 \mu \mathrm{m}$ is considered optimal. ${ }^{92-94}$ The physicochemical characteristics of the scaffold material, such as the geometry, stiffness, nanotopography, wettability, and surface charge, could dramatically affect 
the response of the cells that grow on it, hence tailoring them accordingly is very important..$^{58,84,95-99}$ For an osteoblast to survive in vivo and in vitro, it is very essential that it can adhere to the available surface. ${ }^{100}$ Liu et al reported in their study that cell adhesion events were significantly delayed on hydrophobic surfaces; however, with long-term cultures the bioadhesive outcomes were ultimately almost equal, irrespective of wettability. ${ }^{84}$ The surface roughness (topography) can enhance cell adhesion and the migratory potential of the cells, and it could also affect the cytocompatibility of the osteoblastic cells. ${ }^{95,96,101}$ Currently, the various biomaterials used as scaffolds for bone tissue engineering are biodegradable polymers (eg, poly- $\alpha$-hydroxyl acids like polyglycolic acid, polylactic acid, poly- $\varepsilon$-caprolactone) along with recently explored stable polymers (eg, polypropylene fumarate, polyhydroxyalkonates, and polyurethane), ceramics (eg, hydroxyapatite, coral, bioactive glasses), and natural proteins (eg, collagen). ${ }^{6,14,93,102,103}$ It has been reported that the use of bioadhesive substrates like fibronectin to coat the substrates would aid in osteoblast adhesion, differentiation, and bone formation. ${ }^{104}$ The adhesion is regulated via various integrins and extracellular matrix proteins, which can lead to bondage as fast as within 2 hours, as proved in a study by El-Amin et al using various blocking antibodies. ${ }^{105}$ The biomaterial used as scaffold should specifically interact with the transmembrane receptors expressed by the osteoblasts. ${ }^{58,100}$ Once they attach to a substrate, they are capable of forming mineralized nodules. ${ }^{106}$ Osteointegration following implantation of bone substitutes in vivo or new bone formation in vitro in bone tissue engineering takes place in different stages, starting with recruitment and attachment of osteoprogenitor cells/osteoblasts, their proliferation and differentiation, followed by synthesis and mineralization of the collagenous bone matrix. 1,2,14,107 $^{2}$

\section{Approaches to accelerate osteogenesis}

This can be done by using biomolecules, gene therapy, and innovative scaffold design and culture techniques. Culture conditions such as culture media heavily influence osteoblastic proliferation and differentiation, and the commonly used ones are alpha-modification of Eagle's minimum essential medium or Dulbecco's modified Eagle's medium with serum and osteogenic supplements. ${ }^{108}$ Directed differentiations of stem cells into osteogenic lineage and culturing osteoblastic cells by a cocktail of osteogenic supplements like ascorbic acid, $\beta$-glycerophosphate, and dexamethasone are widely used. ${ }^{6,77,108}$ Ascorbic acid (at a concentration of $50 \mu \mathrm{g} / \mathrm{mL}$ ) aids in production of the collagenous extracellular matrix of bone, associated with higher alkaline phosphatase activity and capability to form mineralized matrix. ${ }^{108}$ $\beta$-glycerophosphate enhances mineralization by the osteoblasts formed, and dexamethasone (at a concentration of $10 \mathrm{nM}$ ) enhances proliferation and differentiation of the concerned cells. $\beta$-glycerophosphate is rapidly hydrolyzed by alkaline phosphatase to produce high levels of phosphate ions, providing an environment suitable for mineral deposition. ${ }^{108}$ Concentration of the $\beta$-glycerophosphate plays an important role, as higher levels can lead to dystrophic calcification, as opposed to the desired bone-like mineralization. ${ }^{58,109}$ The basic culture media help in expansion of cells to achieve higher cell numbers before actually seeding the scaffolds or purely cell-based therapies, whereas the various supplements mentioned stimulate osteoblastic differentiation and maturation or stimulate angiogenesis. It is reported that serum is essential to induce osteogenic differentiation of the hMSCs or it has to be substituted by growth factors like EGF and bFGF and culturing of osteoblastic cells. ${ }^{10,111}$ Addition of various growth factors like BMPs, platelet-rich plasma, VEGF, and hormones like estrogen (based on its antiapoptotic properties), PTH, or vitamin D3 to the osteoblast culture may prove to be useful. , $^{3,32,112-114}$ Cheng et al reported that while BMP-2, 6, and 9 could play an important role in prompting osteoblastic differentiation of MSCs, most BMPs would stimulate osteogenesis in mature osteoblasts. ${ }^{22}$ A study by Balasch has reported increased proliferation of osteoblasts and MSCs even with low doses of oestradiol. ${ }^{115}$ Drugs like statins, especially the hydrophobic ones, increase the VEGF expression in osteoblastic cells' reduced protein prenylation and the phosphatidylinositide-3 kinase pathway, encouraging osteoblastic differentiation. ${ }^{116}$ Dwelling into the signaling pathways of mineralization it is also proposed that drugs targeting the ERK pathways may help in mineralization as it is a negative regulator of skeletal mineralization, as reported by Kono et al. ${ }^{117}$ Osteoblastic cells are sensitive to culture conditions like oxygen and ionic concentrations, $\mathrm{pH}$, or osmotic changes. ${ }^{6,58,98,106,118}$ Accumulating evidence shows that oxygen concentration also plays an important role in bone formation and that osteoblastic cells cultured under hypoxic conditions (under $2 \%$ oxygen tension) show reduction in mineralization, collagen production, and relevant gene expression. ${ }^{119}$

Gene therapy is widely used in tissue engineering and can be done in vitro or in vivo, by viral or nonviral methods, and with or without scaffolds. ${ }^{120}$ The in vivo procedure involves the direct delivery of genes to the site of interest, relying on the transduction of target cells in situ, whereas the in vitro 
approach involves culturing of target cells in the laboratory and genetic manipulation before implanting in the body. ${ }^{12,120}$ Genes encoding growth factor proteins when transfected in the target cells, can secrete the concerned proteins into their vicinity accelerating bone repair. ${ }^{93,112}$ Gene therapy is used to prolong the effects of cell-based therapies using osteoblasts for bone tissue engineering, and the number of genes involved in bone regeneration and repair are potential candidates for gene therapy, such as BMPs, PTH, VEGF, LIM-mineralization protein-1, and transcription factors Runx2 and osterix, or to tackle genetic disorders like osteogenesis imperfecta. ${ }^{6,22,35,93,112,120,121}$ Specific transcription factors like forkhead box class $\mathrm{O}$ (FOXO1) could also offer an effective defense mechanism against the oxidative stress that is reported to be an etiological factor in bone disorders like osteoporosis. ${ }^{32}$ It has been proven in studies that FOXO1 also increases the osteogenic potential of the MSCs via suppression of peroxisome proliferator-activated receptor. $^{122,123}$

Numerous novel scaffolds are being designed to increase osteoblast adhesion, survival, proliferation, differentiation, and matrix production and to make them more susceptible to different forms of stimulation provided as mechanical conditioning. ${ }^{3,6,100}$ Osteoblasts are sensitive to small strains and stimulated by mechanical and electrical forces by activation of cytoskeletal-integrin interactions and related signaling pathways. ${ }^{93}$ There are controlled release scaffolds created from polymers or ceramics with a variety of growth factors and drugs like statins and bisphosphonates incorporated into them for slow release. ${ }^{124}$ As bone cells respond positively to the mechanical stimulation, certain bioreactors, as mentioned below, optical tweezers, or mechanosensitive scaffolds like Bay K8644 incorporated scaffolds (which is a known voltage-operated calcium channel agonist prolonging the ion channel opening time) are being experimented with. ${ }^{6,93,99,107}$
Efforts could also be made with piezoelectric scaffolds or radiopaque scaffolds, which would be easier to monitor once implanted in vivo. Nanofibres or scaffolds with nanotopography manufactured by methods like electrospinning, lithography, or microcontact printing are being increasingly used in bone tissue engineering, as osteoblasts adhere more strongly to the nanostructures than microstructured scaffolds due to their biomimetic nature, large surface area, better osteointegrative properties, and mechanical reliability. ${ }^{6,125}$ Cells are known to grow best on scaffolds with rigidity similar to their native tissues; incorporating bioceramics in scaffolds, especially biodegradable types like carbonated hydroxyapatite, would be recommended. , $^{6,9,126}$

Co-culturing osteoblasts with other cells such as endothelial cells or osteoclasts provide a biomimetic environment, and the cell-to-cell communication activates the signaling pathways that are inherent to native bone formation, leading to increased mineralized matrix secreted and better vascularized bone tissue, as compared to only osteoblast culture. ${ }^{12,19,127,128}$ The results from the Kyriakidou et al co-culture study highlight how osteoblasts increase endothelial cell proliferation and simultaneously endothelial cells increase the growth of osteoblasts but decrease their differentiation. ${ }^{128}$ There are numerous reports of osteoblast-osteoclast co-cultures, which require optimized ratios of both the cells used and special media formulations containing chemicals like RANKL in addition to the usual osteogenic supplements, with good results. ${ }^{12,127}$ For cases like osteoarthritis where joint replacement is required, an osteochondral construct is desirable, and hence efforts are being made to manufacture a hybrid scaffold where both osteogenic and chondrogenic cells could be grown. ${ }^{129-131}$

Various bioreactors have been designed for in vitro production of bone and are being widely used; some of the examples are rotating wall vessel reactors, perfusion

$\begin{array}{ll}\begin{array}{l}\text { Endochondral ossification } \\ \text { In utero formation of long bones }\end{array} & \begin{array}{l}\text { Bone forms from } \\ \text { cartilage }\end{array} \\ \begin{array}{l}\text { Intramembranous ossification } \\ \text { In utero formation of flat bones }\end{array} & \begin{array}{l}\text { Bone forms from } \\ \text { mesenchyme tissue }\end{array} \\ \begin{array}{l}\text { Fracture repair } \\ \text { Wound healing }\end{array} & \text { Callus formation } \\ \begin{array}{l}\text { Appositional growth } \\ \text { Increasing bone diameter }\end{array} & \begin{array}{l}\text { New bone forms at the } \\ \text { surface of bone }\end{array}\end{array}$

Figure $\mathbf{5}$ The paths of natural bone formation in the human body and how researchers have used these as the basis for their tissue engineering approaches. 
bioreactors, magnetic force bioreactor, or the commercially marketed Bose ElectroForce Biodynamic chamber, which improves the quality of tissue produced considerably. ${ }^{6,25,132-135}$ These improve the nutrient mass transfer by enhancing the oxygen and the soluble nutrients beyond the reported distance of $200 \mu \mathrm{m}$ by passive diffusion and also could provide mechanical stimulation aiding in providing a threedimensional environment for cell growth, accelerating cellular aggregation and mineralization. ${ }^{25,93}$

The piezoelectricity of the collagen fibers, together with streaming potentials and streaming currents, are the main factors behind the bioelectricity in bone. This endogenous electricity in turn acts as a guiding cue in the remodeling and healing of bone. ${ }^{136-138}$ These observations provide the basis for the application of electrical stimulation as an osteoinductive tool in medicine. Currently, a diverse range of bone growth stimulators are in existence and are used in the treatment of ailments such as osteoporosis, osteoarthrosis, and nonunion fractures. ${ }^{136,139-144}$ Laboratory studies have confirmed the beneficial nature of electrical stimuli and shown their ability to promote both proliferation and the expression of genes such as $B M P-2, B M P-4$, transforming growth factor $\beta-1$, $A L P$, prostaglandin $\mathrm{E}$ and $V E G F .{ }^{137,138,141,145-152}$ This makes electrical stimulation a modality that could greatly improve our ability to generate tissue engineering constructs and their integration after implantation.
Regarding the physiological information presented earlier in this review, it is possible to draw parallels with approaches and techniques that researchers have used in their studies. These approaches are demonstrated schematically in Figure $5 \cdot{ }^{60,78,106,129,153-156}$

\section{Challenges faced by bone tissue engineering and future strategies}

Tissue engineering faces numerous challenges that researchers are currently addressing: the difficulties of in vitro cell culture, mimicking the exact osteogenesis as in the native tissue, sterility issues, cost factors, and large-scale applications..$^{35}$ Areas that need to be improved include the translation of basic research into viable clinical treatments for bone regeneration. ${ }^{55}$ The cellular interactions between the three types of bone cells are crucial and need to be replicated in the three-dimensional laboratory environment, which at this point is in need of improvement. ${ }^{44,157}$ Though calcium phosphate is reported to be formed, a physiologically bonelike mineral has not been demonstrated decisively, and it has been found that in spite of osteoblasts following the same developmental sequence as those in vivo, there is a lengthened matrix maturation time. ${ }^{58,85}$ The major hurdle in bone tissue engineering has been angiogenesis in the bioengineered bone, and the roles of various angiogenic factors in interactions between osteoblasts and endothelial cells

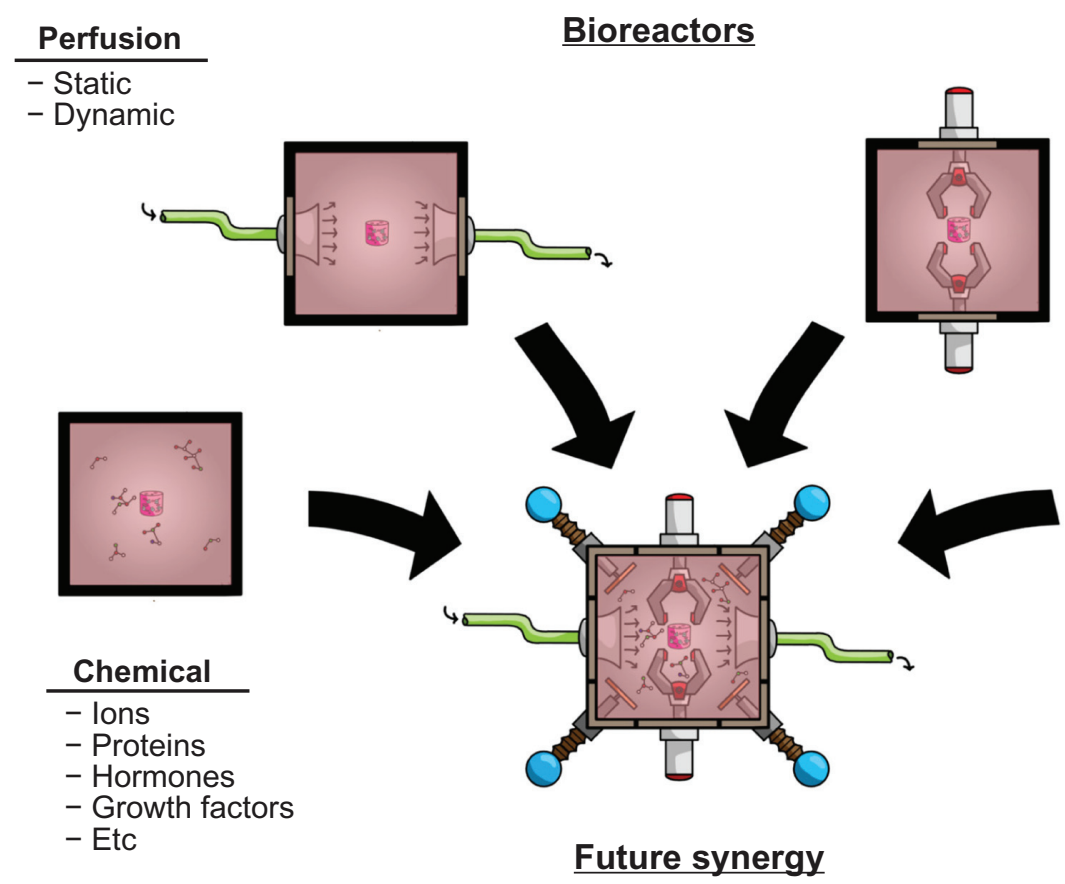

Mechanical

- Compression

- Tension

- Bending

- Torsion

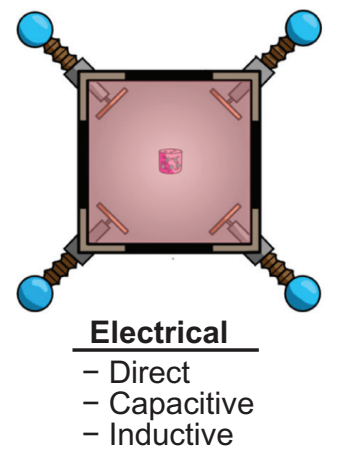

Figure 6 The novel bioreactor technology used in the generation of tissue engineered bone implants.

Notes: As the key to the creation of the best possible quality implants is arguably the best possible approximation of the in vivo environment, the future synergy of all these systems is likely. There are examples of this trend already in existence. 
are areas of intense research. ${ }^{14,15,23,58,113,158}$ Also, the issue of biosafety in tissue engineering when osteoblast-like cells are used persists, as it is reported that these cells may eventually show numerous chromosomal abnormalities. ${ }^{159}$

These issues, however, are all being addressed by researchers, as described above. In order to realistically create a functional tissue implant in a clinically realistic in vitro culture time (4-6 weeks), it is likely that in the future the stimuli and optimized factors that contribute to bone tissue engineering need to be combined. The schematic demonstrated in Figure 6 summarizes this process. This synergistic approach will be the way forward in creating functional tissue engineered constructs for patient therapies.

\section{Disclosure}

The authors report no conflicts of interest in this work.

\section{References}

1. Bilezikian JP, Raisz LG, Martin TJ, editors. Principles of Bone Biology, 3rd ed. New York: Academic Press; 2008.

2. Hing KA. Bone repair in the twenty-first century: biology, chemistry or engineering? Philos Transact A Math Phys Eng Sci. 2004;362(1825): 2821-2850.

3. Jayakumar P, Di Silvio L. Osteoblasts in bone tissue engineering. Proc Inst Mech Eng H. 2010;224(12):1415-1440.

4. Hing KA. Bioceramic bone graft substitutes: influence of porosity and chemistry. Int J Appl Ceram Technol. 2005;2(3):184-199.

5. Young B, Lowe JS, Stevens A, Heath JW, editors. Wheater's Functional Histology: A Text and Colour Atlas, 5th ed. Philadelphia: Churchill Livingstone, Elsevier; 2006.

6. Lanza R, Langer R, Vacanti J, editors. Principles of Tissue Engineering, 3rd ed. New York: Academic Press; 2007.

7. Knothe Tate ML. "Whither flows the fluid in bone?" An osteocytes's perspective. J Biomech. 2003;36(10):1409-1424.

8. Lemaire V, Tobin FL, Greller LD, Cho CR, Suva LJ. Modeling the interactions between osteoblast and osteoclast activities in bone remodeling. J Theor Biol. 2004;229(3):293-309.

9. Taylor AF, Saunders MM, Shingle DL, Cimbala JM, Zhou Z, Donahue HJ. Mechanically stimulated osteocytes regulate osteoblastic activity via gap junctions. Am J Physiol Cell Physiol. 2007;292(1): C545-C552.

10. Jørgensen NR, Henriksen Z, Sørensen OH, Eriksen EF, Civitelli R, Steinberg TH. Intercellular calcium signaling occurs between human osteoblasts and osteoclasts and requires activation of osteoclast P2X7 receptors. J Biol Chem. 2002;277(9):7574-7580.

11. Martin TJ, Ng KW. Mechanisms by which cells of the osteoblast lineage control osteoclast formation and activity. J Cell Biochem. 1994;56(3): $357-366$.

12. Heinemann C, Heinemann S, Worch H, Hanke T. Development of an osteoblast/osteoclast co-culture derived by human bone marrow stromal cells and human monocytes for biomaterials testing. Eur Cell Mater. 2011;21:80-93.

13. Yang X, Karsenty G. Transcription factors in bone: developmental and pathological aspects. Trends Mol Med. 2002;8(7):340-345.

14. Kanczler JM, Oreffo RO. Osteogenesis and angiogenesis: the potential for engineering bone. Eur Cell Mater. 2008;15:100-114.

15. Clines GA. Prospects for osteoprogenitor stem cells in fracture repair and osteoporosis. Curr Opin Organ Transplant. 2010;15(1): $73-78$.
16. Rodda SJ, McMohan AP. Distinct roles of Hedgehog and canonical Wnt signaling in specification, differentiation and maintenance of osteoblast progenitors. Development. 2006;133(16):3231-3244.

17. Shapiro F. Bone development and its relation to fracture repair. The role of mesenchymal osteoblasts and surface osteoblasts. Eur Cell Mater. 2008; 15:53-76.

18. Wiesmann HP, Nazer N, Klatt C, Szuwart T, Meyer U. Bone tissue engineering by primary osteoblast-like cells in a monolayer system and 3-dimensional collagen gel. J Oral Maxillofac Surg. 2003;61(12): 1455-1462.

19. Kobayashi Y, Udagawa N, Takahashi N. Action of RANKL and OPG for osteoclastogenesis. Crit Rev Eukaryot Gene Expr. 2009;19(1): $61-72$.

20. Burkhardt R, Kettner G, Böhm W, et al. Changes in trabecular bone, hematopoiesis and bone marrow vessels in aplastic anemia, primary osteoporosis, and old age: a comparative histomorphometric study. Bone. 1987;8(3):157-164.

21. Shirley D, Marsh D, Jordan G, McQuaid S, Li G. Systemic recruitment of osteoblastic cells in fracture healing. J Orthop Res. 2005;23(5): 1013-1021.

22. Cheng H, Jiang W, Phillips FM, et al. Osteogenic activity of the fourteen types of human bone morphogenetic proteins (BMPs). J Bone Joint Surg Am. 2003;85-A(8):1544-1552.

23. Fröhlich M, Grayson WL, Wan LQ, Marolt D, Drobnic M, Vunjak-Novakovic G. Tissue engineered bone grafts: biological requirements, tissue culture and clinical relevance. Curr Stem Cell Res Ther. 2008;3(4):254-264.

24. Athanasopoulos AN, Schneider D, Keiper T, et al. Vascular endothelial growth factor (VEGF)-induced up-regulation of CCN1 in osteoblasts mediates proangiogenic activities in endothelial cells and promotes fracture healing. J Biol Chem. 2007;282(37):26746-26753.

25. Schneider GB, Boehrs JK, Hoopes JV, Seabold DA. Use of 3-dimensional environments to engineer osseous-like tissue. J Dev Biol Tissue Eng. 2011;3(4):42-47.

26. Mayr-Wohlfart U, Waltenberger J, Hausser H, et al. Vascular endothelial growth factor stimulates chemotactic migration of primary human osteoblasts. Bone. 2002;30(3):472-477.

27. Fiedler J, Leucht F, Waltenberger J, Dehio C, Brenner RE. VEGF-A and PIGF-1 stimulate chemotactic migration of human mesenchymal progenitor cells. Biochem Biophys Res Commun. 2005;334(2): 561-568.

28. Kleinheinz J, Stratmann U, Joos U, Wiesmann HP. VEGF-activated angiogenesis during bone regeneration. J Oral Maxillofac Surg. 2005; 63(9):1310-1316

29. Robling AG, Burr DB, Turner CH. Skeletal loading in animals. J Musculoskelet Neuronal Interact. 2001;1(3):249-262.

30. Morris HL, Haycock JW, Reilly GC. The role of mechanotransduction in bone tissue engineering. Eur Cell Mater. 2008;16(S-3):84.

31. Zaidi M. Skeletal remodeling in health and disease. Nat Med. 2007;13(7):791-801.

32. Manolagas SC. From estrogen-centric to aging and oxidative stress: a revised perspective of the pathogenesis of osteoporosis. Endocr Rev. 2010;31(3):266-300.

33. Khosla S, Riggs BL. Pathophysiology of age-related bone loss and osteoporosis. Endocrinol Metab Clin North Am. 2005;34(4): 1015-1030.

34. Jilka RL, Weinstein RS, Takahashi K, Parfitt AM, Manolagas SC. Linkage of decreased bone mass with impaired osteoblastogenesis in a murine model of accelerated senescence. J Clin Invest. 1996;97(7): 1732-1740.

35. Rose FR, Oreffo RO. Bone tissue engineering: hope vs hype. Biochem Biophys Res Commun. 2002;292(1):1-7.

36. nos.org.uk [homepage on the Internet]. National Osteoporosis Society Figures; 2009. Available from: http://www.nos.org.uk/NetCommunity/ admin/Document.Doc?id=47/. Accessed February 29, 2012.

37. Dimitriou R, Jones E, McGonagle D, Giannoudis PV. Bone regeneration: current concepts and future directions. BMC Med. 2011;9:66-75. 
38. Bernstein P, Bornhäuser M, Günther KP, Stiehler M. Bone tissue engineering in clinical application: assessment of the current situation. Orthopade. 2009;38(11):1029-1037.

39. Panetta NJ, Gupta DM, Quarto N, Longaker MT. Mesenchymal cells for skeletal tissue engineering. Panminerva Med. 2009;51(1):25-41.

40. Albert A, Leemrijse T, Druez V, Delloye C, Cornu O. Are bone autografts still necessary in 2006? A three-year retrospective study of bone grafting. Acta Orthop Belg. 2006;72(6):734-740.

41. Laurencin C, Khan Y, El-Amin SF. Bone graft substitutes. Expert Rev Med Devices. 2006;3(1):49-57.

42. Hernigou P, Poignard A, Beaujean F, Rouard H. Percutaneous autologous bone-marrow grafting for nonunions. Influence of the number and concentration of progenitor cells. J Bone Joint Surg Am. 2005; 87(7):1430-1437.

43. Kaigler D, Pagni G, Park CH, Tarle SA, Bartel RL, Giannobile WV. Angiogenic and osteogenic potential of bone repair cells for craniofacial regeneration. Tissue Eng Part A. 2010;16(9):2809-2820.

44. Bueno EM, Glowacki J. Cell-free and cell-based approaches for bone regeneration. Nat Rev Rheumatol. 2009;5(12):685-697.

45. LeGeros RZ. Calcium phosphate-based osteoinductive materials. Chem Rev. 2008;108(11):4742-4753.

46. Bruder SP, Fox BS. Tissue engineering of bone. Cell based strategies. Clin Orthop Relat Res. 1999;367 Suppl:S68-S83.

47. Wenisch S, Trinkaus K, Hild A, et al. Human reaming debris: a source of multipotent stem cells. Bone. 2005;36(1):74-83.

48. Chapman MW, Bucholz R, Cornell C. Treatment of acute fractures with a collagen-calcium phosphate graft material. A randomized clinical trial. J Bone Joint Surg Am. 1997;79(4):495-502.

49. Price CT, Connolly JF, Carantzas AC, Ilyas I. Comparison of bone grafts for posterior spinal fusion in adolescent idiopathic scoliosis Spine (Phila Pa 1976). 2003;28(8):793-798.

50. Kitchel SH. A preliminary comparative study of radiographic results using mineralized collagen and bone marrow aspirate versus autologous bone in the same patients undergoing posterior lumbar interbody fusion with instrumented posterolateral lumbar fusion. Spine J. 2006;6(4): 405-411.

51. McKay B, Sandhu HS. Use of recombinant human bone morphogenetic protein-2 in spinal fusion applications. Spine (Phila Pa 1976) 2002;27(16 Suppl 1):S66-S85.

52. Heino TJ, Hentunen TA. Differentiation of osteoblasts and osteocytes from mesenchymal stem cells. Curr Stem Cell Res Ther. 2008;3(2): $131-145$.

53. Bajada S, Harrison PE, Ashton BA, Cassar-Pullicino VN, Ashammakhi N, Richardson JB. Successful treatment of refractory tibial nonunion using calcium sulphate and bone marrow stromal cell implantation. J Bone Joint Surg Br. 2007;89(10):1382-1386.

54. Tsiridis E, Ali Z, Bhalla A, et al. In vitro proliferation and differentiation of human mesenchymal stem cells on hydroxyapaptite versus human demineralized bone matrix with and without osteogenic protein-1. Expert Opin Biol Ther. 2009;9(1):9-19.

55. Lee K, Chan CK, Patil N, Goodman SB. Cell therapy for bone regeneration - bench to bedside. J Biomed Mater Res B Appl Biomater. 2009;89(1):252-263

56. Vacanti CA, Kim W, Upton J, et al. Tissue-engineered growth of bone and cartilage. Transplant Proc. 1993;25(1 Pt 2):1019-1021.

57. Vacanti CA, Upton J. Tissue-engineered morphogenesis of cartilage and bone by means of cell transplantation using synthetic biodegradable polymer matrices. Clin Plast Surg. 1994;21(3):445-462.

58. Meyer U, Joos U, Wiesmann HP. Biological and biophysical principles in extracorporal bone tissue engineering. Part I. Int J Oral Maxillofac Surg. 2004;33(4):325-332.

59. Vacanti CA, Bonassar LJ, Vacanti MP, Shufflebarger J. Replacement of an avulsed phalanx with tissue engineered bone. $N$ Engl J Med. 2001; 344(20):1511-1514.

60. Quarto R, Mastrogiacomo M, Cancedda R, et al. Repair of large bone defects with the use of autologous bone marrow stromal cells. $N$ Engl J Med. 2001;344(5):385-386.
61. Warnke PH, Wiltfang J, Springer I, et al. Man as living bioreactor: fate of an exogenously prepared customized tissue-engineered mandible. Biomaterials. 2006;27(17):3163-3167.

62. Logeart-Avramoglou D, Anagnostou F, Bizios R, Petite H. Engineering bone: challenges and obstacles. J Cell Mol Med. 2005;9(1):72-84.

63. Muschler GF, Nakamoto C, Griffith LG. Engineering principles of clinical cell-based tissue engineering. J Bone Joint Surg Am. 2004; 86-A(7):1541-1558.

64. Heng BC, Cao T, Stanton LW, Robson P, Olsen B. Strategies for directing the differentiation of stem cells into the osteogenic lineage in vitro. J Bone Miner Res. 2004;19(9):1379-1394.

65. Ng AM, Saim AB, Tan KK, et al. Comparison of bioengineered human bone construct from four sources of osteogenic cells. J Orthop Sci. 2005;10(2):192-199.

66. Kuehnle I, Goodell MA. The therapeutic potential of stem cells from adults. BMJ. 2002;325(7360):372-376.

67. El Tamer MK, Reis RL. Progenitor and stem cells for bone and cartilage regeneration. J Tissue Eng Regen Med. 2009;3(5):327-337.

68. Bajada S, Mazakova I, Richardson JB, Ashammakhi N. Updates on stem cells and their applications in regenerative medicine. J Tissue Eng Regen Med. 2008;2(4):169-183.

69. Bruder SP, Jaiswal N, Haynesworth SE. Growth kinetics, self-renewal, and the osteogenic potential of purified human mesenchymal stem cells during extensive subcultivation and following cryopreservation. J Cell Biochem. 1997;64(2):278-294.

70. Bruder SP, Kurth AA, Shea M, Hayes WC, Jaiswal N, Kadiyala S. Bone regeneration by implantation of purified, culture-expanded human mesenchymal stem cells. J Orthop Res. 1998;16(2):155-162.

71. Kadiyala S, Young RG, Thiede MA, Bruder SP. Culture expanded canine mesenchymal stem cells possess osteochondrogenic potential in vivo and in vitro. Cell Transplant. 1997;6(2):125-134.

72. Richards M, Huibregtse BA, Caplan AI, Goulet JA, Goldstein SA. Marrow-derived progenitor cell injections enhance new bone formation during distraction. J Orthop Res. 1999;17(6):900-908.

73. Baksh D, Song L, Tuan RS. Adult mesenchymal stem cells: characterization, differentiation, and application in cell and gene therapy. J Cell Mol Med. 2004;8(3):301-316.

74. Bianco P, Robey PG, Simmons PJ. Mesenchymal stem cells: revisiting history, concepts, and assays. Cell Stem Cell. 2008;2(4):313-319.

75. Seong JM, Kim BC, Park JH, Kwon IK, Mantalaris A, Hwang YS. Stem cells in bone tissue engineering. Biomed Mater. 2010;5(6):062001.

76. Jäger M, Zilkens C, Bittersohl B, Krauspe R. Cord blood - an alternative source for bone regeneration. Stem Cell Rev. 2009;5(3):266-277.

77. Lanza R, Gearhart J, Hogan B, et al. Wilmut I, editors. Essentials of Stem Cell Biology, 2nd ed. New York: Academic Press; 2009.

78. Marie PJ, Fromigué O. Osteogenic differentiation of human marrowderived mesenchymal stem cells. Regen Med. 2006;1(4):539-548.

79. Le Blanc K, Tammik C, Rosendahl K, Zetterberg E, Ringdén O. HLA expression and immunologic properties of differentiated and undifferentiated mesenchymal stem cells. Exp Hematol. 2003;31(10): $890-896$.

80. Cuomo AV, Virk M, Petrigliano F, Morgan EF, Lieberman JR. Mesenchymal stem cell concentration and bone repair: potential pitfalls from bench to bedside. J Bone Joint Surg Am. 2009;91(5): 1073-1083.

81. Kassem M. Mesenchymal stem cells: biological characteristics and potential clinical applications. Cloning Stem Cells. 2004;6(4): 369-374.

82. Bonab MM, Alimoghaddam K, Talebian F, Ghaffari SH, Ghavamzadeh A, Nikbin B. Aging of mesenchymal stem cell in vitro. BMC Cell Biol. 2006;7:14-20.

83. Jukes JM, van Blitterswijk CA, de Boer J. Skeletal tissue engineering using embryonic stem cells. J Tissue Eng Regen Med. 2010;4(3):165-180.

84. Liu X, Lim JY, Donahue HJ, Dhurjati R, Mastro AM, Vogler EA. Influence of substratum surface chemistry/energy and topography on the human fetal osteoblastic cell line hFOB 1.19: phenotypic and genotypic responses observed in vitro. Biomaterials. 2007;28(31):4535-4550. 
85. Müller U, Imwinkelried T, Horst M, Sievers M, Graf-Hausner U. Do human osteoblasts grow into open-porous titanium? Eur Cell Mater. 2006;11:8-15.

86. Siggelkow H, Rebenstorff K, Kurre W, et al. Development of the osteoblast phenotype in primary human osteoblasts in culture: comparison with rat calvarial cells in osteoblast differentiation. J Cell Biochem. 1999;75(1):22-35.

87. Gentleman E, Swain RJ, Evans ND, et al. Comparative materials differences revealed in engineered bone as a function of cell-specific differentiation. Nat Mater. 2009;8(9):763-770.

88. Gordeladze JO, Reseland JE, Duroux-Richard I, Apparailly F, Jorgensen C. From stem cells to bone: phenotype acquisition, stabilization, and tissue engineering in animal models. ILAR J. 2010;51(1):42-61.

89. Muschler GF, Raut VP, Patterson TE, Wenke JC, Hollinger JO. The design and use of animal models for translational research in bone tissue engineering and regenerative medicine. Tissue Eng Part B Rev. 2010;16(1):123-145.

90. Osyczka AM, Leboy PS. Bone morphogenetic protein regulation of early osteoblast genes in human marrow stromal cells is mediated by extracellular signal-regulated kinase and phosphatidylinositol 3-kinase signaling. Endocrinology. 2005;146(8):3428-3437.

91. Osyczka AM, Diefenderfer DL, Bhargave G, Leboy PS. Different effects of BMP-2 on marrow stromal cells from human and rat bone. Cells Tissues Organs. 2004;176(1-3):109-119.

92. Petrochenko P, Narayan RJ. Novel approaches to bone grafting: porosity, bone morphogenetic proteins, stem cells, and the periosteum. J Long Term Eff Med Implants. 2010;20(4):303-315.

93. Wiesmann HP, Joos U, Meyer U. Biological and biophysical principles in extracorporal bone tissue engineering. Part II. Int J Oral Maxillofac Surg. 2004;33(6):523-530.

94. Murphy CM, Haugh MG, O'Brien FJ. The effect of mean pore size on cell attachment, proliferation and migration in collagen-glycosaminoglycan scaffolds for bone tissue engineering. Biomaterials. 2010;31(3):461-466.

95. Lampin M, Warocquier-Clérout R, Legris C, Degrange M, Sigot-Luizard MF. Correlation between substratum roughness and wettability, cell adhesion, and cell migration. J Biomed Mater Res. 1997;36(1):99-108.

96. Naji A, Harmand MF. Study of the effect of the surface state on the cytocompatibility of a Co-Cr alloy using human osteoblasts and fibroblasts. J Biomed Mater Res. 1990;24(7):861-871.

97. Reilly GC, Engler AJ. Intrinsic extracellular matrix properties regulate stem cell differentiation. J Biomech. 2010;43(1):55-62.

98. Redey SA, Nardin M, Bernache-Assolant D, et al. Behaviour of human osteoblastic cells on stoichiometric hydroxyapatite and type A carbonate apatite: role of surface energy. J Biomed Mater Res. 2000;50(3):353-364.

99. Yang Y, El Haj A. Enhancement of mechanical signals for tissue engineering bone. In: Ashammakhi N, Reis RL, editors. Topics in Tissue Engineering. Vol 2 [e-book]. 2005.

100. Hidalgo-Bastida LA, Cartmell SH. Mesenchymal stem cells, osteoblasts and extracellular matrix proteins: enhancing cell adhesion and differentiation for bone tissue engineering. Tissue Eng Part B Rev. 2010;16(4):405-412.

101. Oh S, Oh N, Appleford M, Ong JL. Bioceramics for tissue engineering applications - a review. Am J Biochem Biotechnol. 2006;2(2): 49-56.

102. Hutmacher DW. Scaffolds in tissue engineering bone and cartilage. Biomaterials. 2000;21(24):2529-2543.

103. Vagaská B, Bacáková L, Filová E, Balík K. Osteogenic cells on bio-inspired materials for bone tissue engineering. Physiol Res. 2010;59(3):309-322.

104. Garcia AJ, Reyes CD. Bio-adhesive surfaces to promote osteoblast differentiation and bone formation. J Dent Res. 2005;84(5): 407-413.
105. El-Amin SF, Kofron MD, Attawia MA, Lu HH, Tuan RS, Laurencin CT. Molecular regulation of osteoblasts for tissue engineered bone repair. Clin Orthop Relat Res. 2004;427:220-225.

106. Gough JE, Jones JR, Hench LL. Nodule formation and mineralization of human primary osteoblasts cultured on a porous bioactive glass scaffold. Biomaterials. 2004;25(11):2039-2046.

107. Yang Y, Magnay JL, Cooling L, El HA. Development of a 'mechano-active' scaffold for tissue engineering. Biomaterials. 2002;23(10):2119-2126.

108. Coelho MJ, Fernandes MH. Human bone cell cultures in biocompatility testing. Part II: effect of ascorbic acid, beta-glycerophosphate and dexamethasone on osteoblastic differentiation. Biomaterials. 2000;21(11):1095-1102.

109. Chung CH, Golub EE, Forbes E, Tokuoka T, Shapiro IM. Mechanism of action of beta-glycerophosphate on bone cell mineralization. Calcif Tissue Int. 1992;51(4):305-311.

110. Solmesky L, Lefler S, Jacob-Hirsch J, Bulvik S, Rechavi G, Weil M. Serum free cultured bone marrow mesenchymal stem cells as a platform to characterize the effects of specific molecules. PLoS One. 2010;5(9):pii. e12689.

111. Suzuki A, Guicheux J, Palmer G, et al. Evidence for a role of p38 MAP kinase in expression of alkaline phosphatase during osteoblastic cell differentiation. Bone. 2002;30(1):91-98.

112. Fischer J, Kolk A, Wolfart S, et al. Future of local bone regeneration - protein versus gene therapy. J Craniomaxillofac Surg. 2011;39(1):54-64.

113. Cenni E, Perut F, Baldini N. In vitro models for the evaluation of angiogenic potential in bone engineering. Acta Pharmacol Sin. 2011;32(1):21-30

114. Arvidson K, Abdallah BM, Applegate LA, et al. Bone regeneration and stem cells. J Cell Mol Med. 2011;15(4):718-746.

115. Balasch J. Sex steroids and bone: current perspectives. Hum Reprod Update. 2003;9(3):207-222.

116. Maeda T, Kawane T, Horiuchi N. Statins augment vascular endothelial growth factor expression in osteoblastic cells via inhibition of protein prenylation. Endocrinology. 2003;144(2):681-692.

117. Kono SJ, Oshima Y, Hoshi K, et al. Erk pathways negatively regulate matrix mineralization. Bone. 2007;40(1):68-74.

118. Sorkin AM, Dee KC, Knothe Tate ML. "Culture shock" from the bone cell's perspective: emulating physiological conditions for mechanobiological investigations. Am J Physiol Cell Physiol. 2004;287(6):1527-1536.

119. Nicolaije C, Koedam M, van Leeuwen JP. Decreased oxygen tension lowers reactive oxygen species and apoptosis and inhibits osteoblast matrix mineralization through changes in early osteoblast differentiation. J Cell Physiol. 2012;227(4):1309-1318.

120. Heyde M, Partridge KA, Oreffo RO, Howdle SM, Shakesheff KM, Garnett MC. Gene therapy used for tissue engineering applications. J Pharm Pharmacol. 2007;59(3):329-350.

121. Chamberlain JR, Schwarze U, Wang PR, et al. Gene targeting in stem cells from individuals with osteogenesis imperfecta. Science. 2004;303(5661):1198-1201.

122. Dowell P, Otto TC, Adi S, Lane MD. Convergence of peroxisome proliferator-activated receptor gamma and Foxo1 signaling pathways. J Biol Chem. 2003;278(46):45485-45491.

123. Akune T, Ohba S, Kamekura S, et al. PPAR $\gamma$ insufficiency enhances osteogenesis through osteoblast formation from bone marrow progenitors. J Clin Invest. 2004;113(6):846-855.

124. Cartmell S. Controlled release scaffolds for bone tissue engineering. J Pharm Sci. 2009;98(2):430-441.

125. Saranya N, Saravanan S, Moorthi A, Ramyakrishna B, Selvamurugan N. Enhanced osteoblast adhesion on polymeric nano-scaffolds for bone tissue engineering. J Biomed Nanotechnol. 2011;7(2):238-244.

126. Guilak F, Cohen DM, Estes BT, Gimble JM, Liedtke W, Chen CS. Control of stem cell fate by physical interactions with the extracellular matrix. Cell Stem Cell. 2009;5(1):17-26. 
127. Jones GL, Marshall MJ, El Haj AJ, Cartmell SH. Establishing an osteoblast-osteoclast co-culture system for use in bone tissue engineering. Eur Cell Mater. 2006;11(S3):75.

128. Kyriakidou K, Lucarini G, Zizzi A, et al. Dynamic co-seeding of osteoblast and endothelial cells on 3D polycaprolactone scaffolds for enhanced bone tissue engineering. J Bioactive Compatible Polymers. 2008;23(3):227-243.

129. Sundelacruz S, Kaplan DL. Stem cell- and scaffold-based tissue engineering approaches to osteochondral regenerative medicine. Semin Cell Dev Biol. 2009;20(6):646-655.

130. Martin I, Miot S, Barbero A, Jakob M, Wendt D. Osteochondral tissue engineering. J Biomech. 2007;40(4):760-765.

131. Yang PJ, Temenoff JS. Engineering orthopedic tissue interfaces. Tissue Eng Part B Rev. 2009;15(2):127-141.

132. Sittichockechaiwut A, Scutt AM, Ryan AJ, Bonewald LF, Reilly GC. Use of rapidly mineralising osteoblasts and short periods of mechanical loading to accelerate matrix maturation in 3D scaffolds. Bone. 2009;44(5):822-829.

133. Dobson J, Cartmell SH, Keramane A, El Haj AJ. Principles and design of a novel magnetic force mechanical conditioning bioreactor for tissue engineering, stem cell conditioning, and dynamic in vitro screening. IEEE Trans Nanobioscience. 2006;5(3):173-177.

134. Hughes S, Dobson J, El Haj AJ. Magnetic targeting of mechanosensors in bone cells for tissue engineering applications. J Biomech. 2007; 40 Suppl 1:S96-S104.

135. Yeatts AB, Fisher JP. Bone tissue engineering bioreactors: dynamic culture and the influence of shear stress. Bone. 2011;48(2):171-181.

136. Brighton CT, Wang W, Seldes R, Zhang G, Pollack SR. Signal transduction in electrically stimulated bone cells. J Bone Joint Surg Am. 2001;83-A(10):1514-1523.

137. Ercan B, Webster TJ. The effect of biphasic electrical stimulation on osteoblast function at anodized nanotubular titanium surfaces. Biomaterials. 2010;31(13):3684-3693.

138. Kim IS, Song JK, Zhang YL, et al. Biphasic electric current stimulates proliferation and induces VEGF production in osteoblasts. Biochim Biophys Acta. 2006;1763(9):907-916.

139. Brighton CT, Black J, Friedenberg ZB, Esterhai JL, Day LJ, Connolly JF. A multicenter study of the treatment of non-union with constant direct current. J Bone Joint Surg Am. 1981;63(1):2-13.

140. Evans RO, Goldberg JA, Bruce WJ, Walsh W. Reoperated clavicular nonunion treated with osteogenic protein 1 and electrical stimulation. J Shoulder Elbow Surg. 2004;13(5):573-575.

141. Kim IS, Song JK, Song YM, et al. Novel effect of biphasic electric current on in vitro osteogenesis and cytokine production in human mesenchymal stromal cells. Tissue Eng Part A. 2009;15(9): 2411-2422.

142. Spadaro JA, Becker RO. Function of implanted cathodes in electrodeinduced bone growth. Med Biol Eng Comput. 1979;17(6):769-775.

143. Thamsborg G, Florescu A, Oturai P, Fallentin E, Tritsaris K, Dissing S. Treatment of knee osteoarthritis with pulsed electromagnetic fields: a randomized, double-blind, placebo-controlled study. Osteoarthritis Cartilage. 2005;13(7):575-581.

144. Toth JM, Seim HB 3rd, Schwardt JD, Humphrey WB, Wallskog JA, Turner AS. Direct current electrical stimulation increases the fusion rate of spinal fusion cages. Spine (Phila Pa 1976). 2000;25(20): $2580-2587$

\section{Cell Health and Cytoskeleton}

\section{Publish your work in this journal}

Cell Health and Cytoskeleton is an international, peer-reviewed open access journal focusing on all aspects of cell structure and function contributing to normal physiology and cell health and exploring the pathogenesis of cell dysfunction leading to adverse conditions and disease in the organism. The journal welcomes papers covering original research,
145. Kim IS, Song JK, Song YM, et al. Novel action of biphasic electric current in vitro osteogenesis of human bone marrow mesenchymal stromal cells coupled with VEGF production. Bone. 2008;43(Suppl 1):S43-S44.

146. Wiesmann H, Hartig M, Stratmann U, Meyer U, Joos U. Electrical stimulation influences mineral formation of osteoblast-like cells in vitro. Biochim Biophys Acta. 2001;1538(1):28-37.

147. Vander Molen MA, Donahue HJ, Rubin CT, Mcleod KJ. Osteoblastic networks with deficient coupling: differential effects of magnetic and electric field exposure. Bone. 2000;27(2):227-231.

148. Hartig M, Joos U, Wiesmann HP. Capacitively coupled electric fields accelerate proliferation of osteoblast-like primary cells and increase bone extracellular matrix formation in vitro. Eur Biophys $J$. 2000;29(7):499-506.

149. Lohmann CH, Schwartz Z, Liu Y, et al. Pulsed electromagnetic fields affect phenotype and connexin 43 protein expression in MLO-Y4 osteocyte-like cells and ROS 17/2.8 osteoblast-like cells. J Orthop Res 2003;21(2):326-334.

150. Chang K, Chang WH, Huang S, Huang S, Shih C. Pulsed electromagnetic fields stimulation affects osteoclast formation by modulation of osteoprotegerin, RANK ligand and macrophage colonystimulating factor. J Orthop Res. 2005; Nov;23(6):1308-1314.

151. Bodamyali T, Bhatt B, Hughes FJ, et al. Pulsed electromagnetic fields simultaneously induce osteogenesis and upregulate transcription of bone morphogenetic proteins 2 and 4 in rat osteoblasts in vitro. Biochem Biophys Res Commun. 1998;250(2):458-461.

152. Zhuang H, Wang W, Seldes RM, Tahernia AD, Fan H, Brighton CT. Electrical stimulation induces the level of TGF-beta1 mRNA in osteoblastic cells by a mechanism involving calcium/calmodulin pathway. Biochem Biophys Res Commun. 1997;237(2):225-229.

153. Bokhari MA, Akay G, Zhang S, Birch MA. The enhancement of osteoblast growth and differentiation in vitro on a peptide hydrogelpolyHIPE polymer hybrid material. Biomaterials. 2005;26(25): 5198-5208.

154. Fuchs S, Ghanaati S, Orth C, et al. Contribution of outgrowth endothelial cells from human peripheral blood on in vivo vascularization of bone tissue engineered constructs based on starch polycaprolactone scaffolds. Biomaterials. 2009;30(4):526-534.

155. Santos MI, Unger RE, Sousa RA, Reis RL, Kirkpatrick JC. Crosstalk between osteoblasts and endothelial cells co-cultured on a polycaprolactone-starch scaffold and the in vitro development of vascularization. Biomaterials. 2009;30(26):4407-4415.

156. Ghanaati S, Unger RE, Webber MJ, et al. Scaffold vascularization in vivo driven by primary human osteoblasts in concert with host inflammatory cells. Biomaterials. 2011;32(32):8150-8160.

157. Pirraco RP, Marques AP, Reis RL. Cell interactions in bone tissue engineering. J Cell Mol Med. 2010;14(1-2):93-102.

158. Santos MI, Reis RL. Vascularization in bone tissue engineering: physiology, current strategies, major hurdles and future challenges Macromol Biosci. 2010;10(1):12-27.

159. Magdolen U, Schmitt M, Hildebrandt B, et al. Spontaneous in vitro transformation of primary human osteoblast-like cells. Cancer Genomics Proteomics. 2010;7(2):61-66.

\section{Dovepress}

basic science, reviews and evaluations, guidelines, expert opinion and commentary, case reports and extended reports. The manuscript management system is completely online and includes a very quick and fair peerreview system, which is all easy to use. Visit http://www.dovepress.com/ testimonials.php to read real quotes from published authors. 